\title{
Classification and Pay Plan for University Libraries
}

Mr. Grazier is circulation librarian of Pennsylvania State College Library, State College.

$\mathrm{I}^{\mathrm{N}}$ N PRESENTING an informal paper to a local library staff association on library personnel the writer devoted one part of it to the recently published Classification and Pay Plans for Libraries in Institutions of Higher Education-University Libraries. ${ }^{1}$ A sketchy comparison was drawn between the classification and pay plan and the personnel organization of the Pennsylvania State College Library. Skeletal as the comparison was, the several disparities revealed between theory and practice were rather startling, startling enough perhaps to prove of some interest to other library staffs.

The first step in making the comparison was to determine the service load of the Pennsylvania State College Library. The pay plans wisely abandoned the former concept of the service load as being based on total enrolment and developed a method of computing the service load in terms of service units which are based on varying numbers of underclass and upperclass students, honors students, graduate students, and faculty members. The weights used

1 Subcommittee on Budgets, Compensation, and Schemes of Service for Libraries Connected with Universities, Colleges, and Teacher-Training Institutions of the A.L.A. Board on Salaries, Staff, and

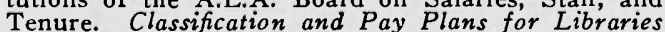
in Institutions of Higher Education. Volume 3, in Institutions of Higher Education. Volume 3,
Universities. Chicago, American Library Association, I 943. were: undergraduates $\mathrm{I}$, upperclass (juniors and seniors) 2 , honors students 3 , graduate students 4 , and faculty 5 . The total service unit is obtained by adding the number of units in each category. The service load of the Pennsylvania State College Library approximated 13,500 units, which put it, according to the classification and pay plan, into class six, which is university libraries having 10,000-I4,999 service units.

The class of the library established, the next step was to compare the total staff organization, including professional and clerical help of our library, with the standard set up by the schedule. Minimum standards for a class six university library called for twenty-nine professional librarians in addition to the chief librarian. Actually there are twenty-five professionals in addition to our chief librarian. The clerical service should result in not more than 60 per cent or less than 40 per cent of the total staff hours being of clerical or student service. Penn State's clerical service was 54 per cent of total staff time, a figure which came within the set limit.

Only four departments were selected to carry on the comparison of the theory with the practice: the catalog, reference, order, and circulation departments. They were chosen primarily because they lent themselves to such a comparison more readily than other phases of Pennsylvania State College Library organization. And even 
the comparisons of these four departments were limited to only the most general features of the classification and pay plans. As the compilers constantly reiterate, a thorough job analysis of each position is necessary before any accurate evaluation can be made. Since the entire comparison was only part of a general talk on the question of personnel related to the Pennsylvania State College Library, only the most incomplete and general analyses described here were undertaken. Two factors, however, made a few comparisons valid, despite the lack of a job analysis. First, the class of any individual library can be determined by computing its service load, and each class has certain minimum standards which should be met by all libraries falling within that particular class. Secondly, the class of any department is automatically determined by the number of employees in the department. According to the classification scheme there are five classes of departments ranging from $\mathrm{A}$ to $\mathrm{E}, \mathrm{A}$ being the smallest and $\mathrm{E}$ the largest. Standards of education, experience, personal qualifications, and a salary schedule are set up for each position within each class of department. Thus, as has been stated, the numerical size of a department determines its class and to a certain limited extent the standards of each position within that particular department.

\section{Procedure for Comparison}

The procedure for comparing standards is the same for each department. A brief description of the general process involved in evaluating the standards of our catalog department will explain the process followed for the other departments.

According to the classification and pay plan our catalog department is a class D catalog department. A class D catalog department has a staff of II-I 4 full-time members including clerical help plus the chief of the department. There are five classes of catalog departments ranging from A with a staff of 2-4 to $E$ with a staff of 15 or more. It is to be noted that the numerical size of the department determines its class and ultimately the qualification and salaries of positions.

Turning to the personnel specification section of the pay plan, it states that the chief catalog librarian of a class D catalog department is of professional grade 6 . There are ten professional grades of position ranging from I to Io, unit Io being the highest. Each grade includes various positions; i.e., grade 3 includes chief reference librarian for class $A$ reference department, document librarian, assistant chief librarian of class I library, and approximately 33 other professional positions. Each grade has a salary schedule and all positions of the same grade have the same salary schedule and the same minimum educational qualifications and experience. The chief catalog librarian is professional grade 6 and should receive an annual salary ranging from $\$ 3600$ to $\$ 4500$. The assistant chief catalog librarian is professional grade 5, salary $\$ 3000$ to $\$ 3400$. In addition to these two positions, the classification plan provides the following positions for a class $\mathrm{D}$ catalog department : catalog librarian (reviser), professional grade 3 or 4 , salary $\$ 1860$ to $\$ 2340$ or $\$ 2400$ to $\$ 2880$; catalog librarian (specialist in a subject or language field), professional grade 3 or 4 , salary $\$ 1860$ to $\$ 2340$ or $\$ 2400$ to $\$ 2880$; classification librarian, professional grade 3 or 4 , salary $\$ 1860$ to $\$ 2340$ or $\$ 2400$ to $\$ 2880$; senior catalog librarian, professional grade 3, salary $\$ 1860$ to $\$ 2340$; intermediate cata- 
log librarian, professional grade 2, salary $\$ 1620$ to $\$$ I 800 ; junior catalog librarian, professional grade I, salary $\$ 1500$ to \$1620. These represent the varying ranks of catalog librarian which might be in a class D catalog department.

\section{Classification of Catalogers}

Actually there are only two ranks in our catalog department, catalog librarian and assistant catalog librarian, with four additional professional catalogers unranked. Thus while two of the positions fit the terminology of the national model the other four positions had to be ranked before the department could be evaluated in terms of the classification and pay plan. After studying the duties and the educational requirements of the various cataloging positions specified in the plan, the head of our catalog department assigned the following ranks to our four unclassed professional positions: two senior catalog librarians, one intermediate catalog librarian, and one junior catalog librarian. Hence five grades of professional service are represented in our catalog department: one each of grades 6, 5, 2, and I and two of grade 3. According to the pay plan the average minimum salary of such a catalog department should be $\$ 2240$ per year. It should be remembered that this average is using the minimum of the salary range of each position, i.e., for chief catalog librarian $\$ 3600$ instead of $\$ 4500$. Actually the average salary of the members of the catalog department is $\$ 1667 .{ }^{2}$ The most obvious discrepancy between the classification and pay plan and the library

\footnotetext{
2 A general salary increase for the faculty of the entire college based on the rise in the cost of living has raised this figure to $\$ 1805$. Since the increase, however, was not based on the value of library services, the given figures are a more accurate comparison with any minimum salary schedule. On such a basis, the minimum standards themselves should be raised proportionally.
}

organization of Penn State was this salary factor. The comparative averages of the catalog department were by no means representative of the great extremes between the actual and the minimum standard. For at least one position the minimum salary recommended was IOO per cent above the actual salary. This pessimistic picture was not enhanced by an introductory paragraph in the syllabus which states: "All the standards set up are minimum standards. It is expected that average and better-than-average libraries will exceed these minimum salary schedules for the various grades." Was our library so far below the average that it had 100 per cent difference in actual and minimum standard salaries?

In self-defense it should be stated that the salaries of the Pennsylvania State College Library compare favorably with the average library salaries. No valid statistics are available, but a few isolated figures indicate that the average salary for librarians in I936 was \$I625 per annum. The average salary of a staff member of the Pennsylvania State College Library based on 1942 figures was $\$$ I 749.99. Allowing for the six-year discrepancy in time, the disparity between the two figures is not enough to justify the conclusion that salaries at Penn State are 50 per cent below minimum standards unless it is assumed that salaries the country over bear the same general relation to the standard used.

Cursory application of the pay plan to other departments revealed additional readjustments which would have to be made before a thorough classification could be accomplished. Our reference department ranks as a class A reference department having 2 to 3 full-time members or their equivalents. Only 2 of the mem- 
bers are professional librarians: the reference librarian and the assistant reference librarian. According to the classification plans terminology, "assistant reference librarian" is used only for class D and E reference departments. This represents a typical instance in which the specific library has a titled position which does not appear in the classification plan. A more frequent occurrence is the classification plan having titled positions which the individual library does not have. In both cases the library would have to make up its own classes of positions, based upon the duties of the position plus the professional and personal qualifications of the librarian necessary to capably fill the position. Differences of terminology are minor ones, however; the administrator can easily identify nontitled or unliketitled positions by comparing the duties with those specified in the classified service. The professional grade having been assigned, the salary schedule would be that of other positions of similar grades.

\section{Positions Not Included}

Perhaps an entire department would have to be classified if the department did not appear in the classification plan. This was the case with our serials department, since no separate serials department appeared in the classification plan. The authors are very careful, however, to state explicitly that the omission of a department or a specific position is not to imply that that department or position has no recognized professional status. It simply means that each individual library must work out its own classification and pay plan using the published one as a model to aid and direct its endeavors. The committee constantly reiterates the necessity for each library to set up its own classifi- cation of positions and to assign these positions a certain suggested professional grade which should establish a system of equal pay for equal work.

Salaries in the order and reference departments were much more in line than those of the catalog department. Both are class A departments, having 2-3 fulltime members. The size of a department which determines its class varies for different departments. That is, a class $\mathrm{C}$ catalog department has 8-io full-time members, a class $\mathrm{C}$ order department 6-7 full-time members, and a class $\mathrm{C}$ circulation department I5-1 9 full-time members. The pay plan's average minimum salary for both our reference and order departments would be \$1740; actually it is $\$ 1650 .{ }^{3}$ But the circulation department, like the catalog department, falls considerably below the suggested minimum. With 14 full-time members or their equivalent, the circulation is a class B circulation department. 'Professional members include the chief circulation librarian, assistant chief circulation librarian, and intermediate circulation librarian. Only the last title had to be arbitrarily assigned, our designation being "circulation assistant." The minimum salary schedule would result in an average yearly salary of $\$ 1960$ per member; actually the average salary is \$1533. For our library, salary discrepancies between the actual and the theoretical were greater in the larger departments and in positions having the most administrative responsibility. Should additional applications result in similar conclusions, the plan may reveal that the administrative functions of librarians have been overlooked by those who hold the purse strings.

\footnotetext{
8 These figures, like those of the catalog depart ment, do not take into account the general increase based on rise in cost of living.
} 
A self-evaluating score card to assist in a qualitative and quantitative appraisal of various phases of library administration was eliminated because of war conditions. This omission of a means of testing potential reorganizations is unfortunate since realignments made in libraries during and on account of the war could be evaluated by the score card. In a "normal period" such realignments will be more difficult. To effect alterations, eliminations, and the combining of positions or departments, is an operation which involves obvious difficulties which even the best combination of ruthlessness and tact cannot overcome. It is when positions are voluntarily vacated that reorganization can proceed with a minimum of abrupt adjustments. This is especially true in a profession which tolerates rather than eradicates mediocrity and in which dead wood is permitted to rot in peace rather than be mercifully cut down with the "efficiency axe."

Another omission is the lack of standards for the relative size of departments. While the class of each department is arbitrarily set by the number of people within the department, no suggestion is made as to how large a specific department should be. Ought a class 6 library to have a class $\mathrm{C}$ catalog department? Or should it be a class B or a class D? How large should the circulation department be? The relative size of the various departments may adjust themselves to the needs of the institution. But on the other hand, a one-sided development may occur either through the personal emphasis of the administrator or through the superior initiative of one department head. In either instance the balance of the library organization may be upset, especially if not measured against certain accepted standards. And if such standards are measurable, they should appear in a classification plan.

\section{Education and Experience}

The two factors emphasized in stressing qualifications for positions of various grades are education and experience. These are the prime requisites for personnel specifications for positions in any classification plan, be it for business, industry, or government. Librarianship, however, possesses an attribute which limits the weight of one of these factors. It has a certain educational homogeneity. The great majority of librarians possess similar educational backgrounds, B.A. or B.S. degrees plus library school degrees. Thus promotion to a higher grade of service becomes primarily based on experience. This could result in seniority becoming almost the sole basis of advancement, a practice which has proven to possess the inherent defect of stifling individual ambition and initiative on the theory that time and only time can produce deserved promotions. To avoid this pitfall it will be necessary for administrators to abjure a too slavish adherence to these "necessary professional qualifications." No classification scheme, of course, can form individual qualifications into a set pattern. The disparities of individual worth will have to be determined by the administrator.

Finally, the minimum and maximum salary schedules are extremely high in view of present professional salaries. The librarian who attempts to evaluate his library in the light of the suggested salary levels will be very discouraged. Samples of salary disparities between the pay plan and salaries of the Pennsylvania State College Library have been given. The effort to increase salary levels is necessary 
and praiseworthy, but to raise so much in theory may result in no raise in practice. Administrators and boards of trustees will be hard-pressed to use the committee's minimum and maximum figures as a yardstick to measure current salary schedules. The theory is so far above the practice that the theory may be discarded as sheer wishful thinking. Optimism in planning for the future is good. But when suggested minimum salaries are as much as 50 per cent above normal current salaries, they would seem to me millennial salaries.

But despite its several acknowledged shortcomings, the classification and pay plan, if utilized, is a valuable contribution to the library profession. The committee has prepared a comprehensive and detailed plan by which a librarian can evaluate the personnel and organization of his library.
The plan emphasizes an impersonal and scientific approach to the problems of classification of positions and salary schedules and such an approach is as essential to good administration in libraries as it is in business, industry, and government. The plan is sufficiently flexible to cover the many variations in library organizations which exist even in institutions of comparable size and function. It represents a synthesis of years of library administration of the highest caliber. It provides an excellent opportunity for librarians to evaluate their organizations by tested methods. If its potentialities remain unrealized, the fault will be with library administrators and not with the committee whose efforts have produced an opus worthy the serious consideration of every librarian.

\section{Libraries and the Coming of "Workshops"}

\section{(Continued from page I47)}

the solution of these problems through informal contact with people with like difficulties. In the past the use of books and the truths in them have been objective. We have felt we must keep the library and its services impersonal. We now must take our wares from the formal atmosphere that can be so deadening. We must make our libraries warm and inviting. We must be willing to cooperate, to make education and educational ends interesting, not boring. Now that we are not so oppressed with great numbers of students, we must not be so busy about many things that we cannot talk over problems and books informally with any student. We must simplify the approach to ourselves and to our stock. While the workshop as yet may not be of enough importance in the college picture as a whole to change methods and techniques of library service, it is showing us that the librarian must be approachable enough to contribute to new ideas and to student problems from his own research, his own experience, and his own thinking. $\mathrm{He}$ must have time to show a path through the library material that will help the student to reach his answers as easily and quickly as possible. To paraphrase, he must make "print as exciting and as easy as sin." 